Article

\title{
Treatment of Source-Separated Blackwater: A Decentralized Strategy for Nutrient Recovery towards a Circular Economy
}

\author{
Melesse Eshetu Moges ${ }^{1,2, *}$, Daniel Todt ${ }^{2}$ and Arve Heistad ${ }^{1}$ \\ 1 Faculty of Science and Technology, Norwegian University of Life Sciences (NMBU), P.O. Box 5003, \\ 1432 Akershus, Norway; arve.heistad@nmbu.no \\ 2 Ecomotive AS, Myravegen 1, N-6060 Hareid, Norway; dt@ecomotive.no \\ * Correspondence: melesse.eshetu@nmbu.no; Tel.: +47-91529750
}

Received: 28 March 2018; Accepted: 8 April 2018; Published: 11 April 2018

\begin{abstract}
Using a filter medium for organic matter removal and nutrient recovery from blackwater treatment is a novel concept and has not been investigated sufficiently to date. This paper demonstrates a combined blackwater treatment and nutrient-recovery strategy and establishes mechanisms for a more dependable source of plant nutrients aiming at a circular economy. Source-separated blackwater from a student dormitory was used as feedstock for a sludge blanket anaerobic-baffled reactor. The effluent from the reactor, with $710 \mathrm{mg} \mathrm{L}^{-1} \mathrm{NH}_{4}-\mathrm{N}$ and $63 \mathrm{mg} \mathrm{L}^{-1} \mathrm{PO}_{4}-\mathrm{P}$, was treated in a sequence of upflow and downflow filtration columns using granular activated carbon, Cocos char and polonite as filter media at a flow rate of $600 \mathrm{~L} \mathrm{~m}^{-2}$ day $^{-1}$ and organic loading rate of $430 \mathrm{~g}$ chemical oxygen demand (COD) $\mathrm{m}^{-2}$ day $^{-1}$. Filtration treatment of the anaerobic effluent with carbon adsorbents removed $80 \%$ of the residual organic matter, more than $90 \%$ of suspended solids, and turbidity while releasing more than $76 \% \mathrm{NH}_{4}-\mathrm{N}$ and $85 \%$ of $\mathrm{PO}_{4}-\mathrm{P}$ in the liquid phase. The treatment train also removed total coliform bacteria and E. coli in the effluent, achieving concentrations below detection limit after the integration of ultraviolet (UV) light. These integrated technological pathways ensure simultaneous nutrient recovery as a nutrient solution, pathogen inactivation, and reduction of active organic substances. The treated nutrient-rich water can be applied as a source of value creation for various end-use options.
\end{abstract}

Keywords: source-separation; blackwater treatment; nutrient-recovery; on-site wastewater treatment

\section{Introduction}

Population growth and rapid urbanization during the early 1900s led to the development of synthetic fertilizers to supplement crop production and meet the world's food demand [1,2]. Harnessing $\mathrm{P}$ from phosphate rock reserves, $\mathrm{K}$ from potash reserves and $\mathrm{N}$ fixed from the atmosphere by the Haber-Bosch process helped to spawn the Green Revolution, and resulted in a rapid intensification of anthropogenic flows of N, P and K over the last century [3]. Phosphorus and nitrogen from agricultural food products are transported into cities and eventually end up in domestic wastewater streams. Globally, nearly $20 \%$ of manufactured nitrogen and phosphorous is contained in domestic wastewater $[4,5]$. The majority of these nutrients and organic matter in domestic wastewater come from a small fraction of the wastewater stream-human urine and feces, hereafter called blackwater [6,7]. Most modern cities established centralized sewer systems with a network of collection pipes for transporting domestic wastewater to a municipal wastewater treatment plant, and with that improved public health and environmental quality [8,9]. In these systems, enormous volumes of freshwater are required to transport the small volume of human excreta from the toilet to the 
wastewater treatment plant $[10,11]$. Moreover, the nutrients from the toilet are highly diluted by wastewater from other sources including storm water and groundwater intrusion. Hence, high levels of energy and large amounts of chemicals are needed for processing in order to recover these resources, and significant amounts of nutrients are lost before reaching the treatment plant through leakages and overflows.

Increased demand for water, energy and food by the growing population and the necessity for a simultaneous reduction of the environmental impact of wastewater has increased the need for an innovative solution. Protecting water bodies from eutrophication, ensuring long-term food security and shifting to a circular economy represent compelling objectives for water-, energy- and nutrient-management strategies [12]. In this regard, domestic wastewater can be seen as a resource rich in water, energy and plant nutrients [13-15] with potential to contribute to the circular economy. Using the principles of source-separation, the perception of wastewater treatment is now advancing from end-of-pipe removal of pollutants to the recovery of resources [13,16-18] with the realization of the value of treated water, energy and nutrients. However, many of the energy-recovery technologies and most of the resource-recovery approaches require large-scale operations to be economically viable [19]. Research should focus, therefore, on technologies that could be economically realistic in smaller treatment plants and suitable for small-scale and decentralized systems.

Source-separating and on-site treatment systems allow targeted treatment of source-separated wastewater streams, recovery and reuse of resources and control of pollutants in areas close to the sources [20,21]. By source-separating concentrated blackwater and co-digesting it with wet organic wastes (such as food waste), approximately $90 \%$ of the nitrogen, $74 \%$ of the phosphorus and $79 \%$ of the potassium can be reclaimed and recycled [22,23]. One potential approach to improve the effectiveness of recovery and recycling of nutrients is to couple it with biogas production through anaerobic digestion (AD). Anaerobic digestion alone, however, does not provide the necessary requirement in terms of nutrient recycling. Developing mechanisms for the removal of residual organic contaminants including micropollutants from anaerobically treated blackwater, while keeping essential plant nutrients in the liquid-phase, is vital as a source of value creation and for reducing both health-related and environmental risks. The principal advantages of this proposed system are, therefore, to couple energy recovery from the anaerobic digestion of source-separated blackwater with the production of a high-quality nutrient solution in an economic and environmentally friendly way. This further requires coupling the nutrient-recovery methods with the removal of pathogens and micropollutants such as pharmaceutical residues and personal care products (PPCP). On-site treatment of this untapped valuable resource using the appropriate level of technology and subsequent resource recovery will make source-separation an attractive domestic wastewater management option and a source of value creation.

The aim of this study is twofold: firstly, to develop and demonstrate a combined treatment and resource recovery approach for processing source-separated blackwater; and secondly, to promote closed-loop flows of resources and nutrients within the area close to the source of generation. Thereby, processing units remove organic substances and suspended solids while selectively recovering $\mathrm{P}$ and $\mathrm{N}$ in the liquid-phase as a nutrient solution. When integrated with a disinfection unit, the sanitized water can be applied for different end-use options, and/or safe discharge.

\section{Materials and Methods}

\subsection{Composition of Anaerobically Digested Blackwater Effluent}

Anaerobically treated blackwater effluent from a lab-scale anaerobic sludge blanket reactor [24] was collected in a $12 \mathrm{~L}$ storage tank and used as an inlet for a column filtration study. The composition of the effluent with respect to organic matter (both total and dissolved), total suspended solids (TSS), $\mathrm{pH}$, and dissolved nutrients (mainly $\mathrm{NH}_{4}-\mathrm{N}$ and $\mathrm{PO}_{4}-\mathrm{P}$ ) and E. coli were analyzed using standard methods as described in Section 2.3. 


\subsection{Filtration Column Study}

For this study, three treatments of a sequential upflow and downflow filtration system with granular activated carbon (GAC), Cocos char (CCCH), and coarse polonite (C-Pol) was designed, each with two replications. Thus, 12 columns of $4.2 \mathrm{~cm}$ internal diameter and $41 \mathrm{~cm}$ bed height, filled with GAC, CCCH and C-Pol, were prepared. GAC was obtained from Chemviron Carbon, Calgon Carbon Corporation, Feluy, Belgium. Cocus char was obtained from Haaland A/S Stavanger, Norway and polonite from FANN Miljøteknikk AS, Drøbak, Norway. The operational parameters of this column experiment are shown in Table 1.

Table 1. Operational parameters of the column experimental setup.

\begin{tabular}{|c|c|}
\hline Influent & Anaerobically Digested Blackwater Effluent \\
\hline Column height $(\mathrm{cm})$ & 50 \\
\hline Internal diameter $(\mathrm{cm})$ & 4.2 \\
\hline Area of column $\left(\mathrm{cm}^{2}\right)$ & 13.85 \\
\hline Column material & Plexi Glass \\
\hline Bed height $(\mathrm{cm})$ & $\begin{array}{l}41 \text { of which } 2 \mathrm{~cm} \text { is filled with } 3 \mathrm{~mm} \text { glass beads at the bottom and on } \\
\text { the top of the filter media }\end{array}$ \\
\hline Bed volume $\left(\mathrm{cm}^{3}\right)$ & 553.5 \\
\hline Filter media (adsorbents) & Granular activated carbon, Cocos char $(\mathrm{CCCH})$ and polonite \\
\hline Mass of adsorbent (g) & $200,200,741$, respectively \\
\hline Particle size range $(\mathrm{mm})$ & $0.5-1.4,0.35-1.18$, and $2.8-4$ for GAC, CCCH and polonite, respectively \\
\hline Flow rate $(\mathrm{mL} / \mathrm{h})$ & 35 (corresponds to- $-600 \mathrm{~L} \mathrm{~m}^{-2}$ day $^{-1}$ ) \\
\hline Retention time (h) & $5 \mathrm{~h}$ for $\mathrm{GAC}$ and $\mathrm{CCCH}$ and $7 \mathrm{~h}$ for polonite \\
\hline Mode of flow & $\begin{array}{l}\text { Continuous upflow mode for saturated condition followed by } \\
\text { downflow mode for unsaturated step (without effluent recycling) }\end{array}$ \\
\hline Organic loading rate $\left(\mathrm{g} \mathrm{COD} \mathrm{m}^{-2} \mathrm{day}^{-1}\right)$ & 430 \\
\hline
\end{tabular}

\section{Experimental Setup}

Six columns, represented by CCCH_1, GAC_1 and C-Pol_1 in duplicates for the Cocos char column, granular activated carbon and coarse polonite, respectively, were operated in upflow. The other six, which also represent the final effluent, indicated as CCCH_2, GAC_2 and C-Pol_2 were operated in downflow mode for the three adsorbents in two replications. The particle sizes of the adsorbents range from 0.5-1.4, 0.35-1.18, 2.8-4 mm for GAC, CCCH and C-Pol, respectively. Before packing into the columns, adsorbents were thoroughly washed with tap water to remove fine particles and dried at $105^{\circ} \mathrm{C}$ for $24 \mathrm{~h}$. At the bottom of the filter column, a $1 \mathrm{~mm}$ diameter mesh and $2 \mathrm{~cm}$ of $3 \mathrm{~mm}$ diameter glass beads was placed for uniform distribution of the influent and as supporting material to prevent the particles from entering the inlet tube. Another $2 \mathrm{~cm}$ glass bead of $3 \mathrm{~mm}$ diameter was placed on top of each column to prevent floating of the carbon filter particles in the upflow mode and to allow uniform distribution in the unsaturated column. Figure 1 shows the flow scheme of the sequential upflow and downflow filtration system in two replicates for the three treatments.

The anaerobically digested blackwater was pumped into the first set of six columns in upward flow mode using a multi-channel peristaltic pump from a $12 \mathrm{~L}$ storage tank at a rate of about $600 \mathrm{~L} \mathrm{~m}^{-2} \mathrm{day}^{-1}$. The effluent of the first set of columns then flowed by gravity to the second set of columns in unsaturated flow mode (Figure 1). The final effluent passed through an ultraviolet (UV) light chamber $290 \mathrm{~mm}$ long and $55 \mathrm{~mm}$ diameter with an 11 Watt UV lamp inside a quartz sleeve of $200 \mathrm{~mm}$ length and $40 \mathrm{~mm}$ diameter with a working volume of $0.9 \mathrm{~L}$. The retention time of treated effluent in the UV chamber was about $3 \mathrm{~h}$. Samples were taken from the upflow and downflow effluents for analysis. 


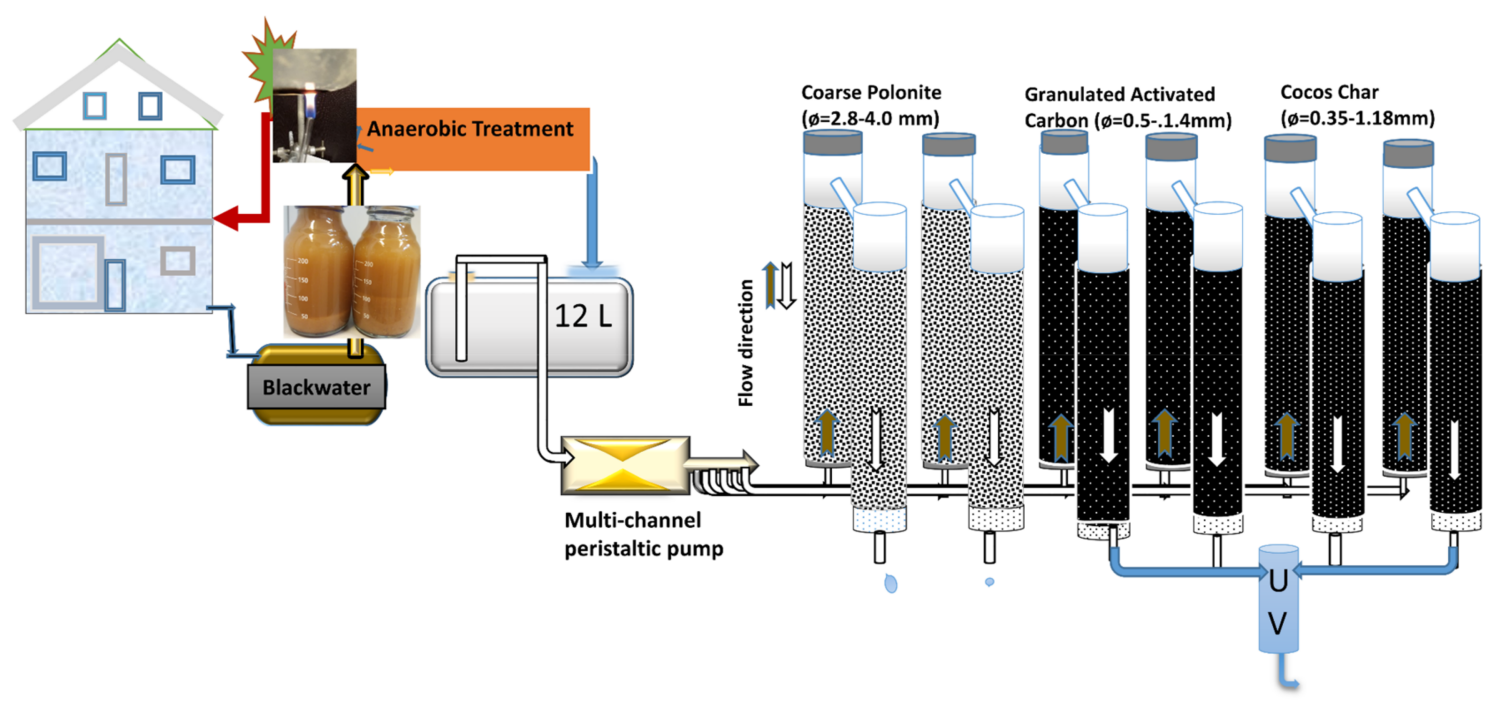

Figure 1. Flow scheme of sequential upflow and downflow filtration system in two replicates for the three treatments: coarse polonite $(\varnothing=2.8-4.0 \mathrm{~mm})$, granulated activated carbon $(\varnothing=0.5-1.4 \mathrm{~mm})$ and Cocos char $(\varnothing=0.35-1.18 \mathrm{~mm})$.

\subsection{Effluent Analysis}

For the first four months, samples of the anaerobically digested blackwater effluent and final filtrate were taken on a weekly basis and analysis for chemical oxygen demand (total CODt and filtered CODf), $\mathrm{pH}$, ammonium nitrogen $\left(\mathrm{NH}_{4}-\mathrm{N}\right)$, soluble phosphorous $\left(\mathrm{PO}_{4}-\mathrm{P}\right)$, and total suspended solids (TSS) were carried out to determine the characteristics and efficiency of the filtration system. After four months, sampling was carried out every two weeks. A limited number of samples were also analyzed for turbidity, $\mathrm{BOD}_{5}, \mathrm{UV}_{254}, \mathrm{NO}_{3}-\mathrm{N}$, and $\mathrm{NO}_{2}-\mathrm{N}$.

Total COD was measured from the unfiltered sample. Filtered COD, $\mathrm{PO}_{4}-\mathrm{P}$, and $\mathrm{NH}_{4}-\mathrm{N}$ were measured from filtered samples using $1.2 \mu \mathrm{m}$ glass fiber filters. CODt and CODf concentrations were analyzed using spectrophotometric test kits (Hach-Lange, Berlin, Germany) LCK 014 and LCK 514, respectively. Soluble phosphate and $\mathrm{NH}_{4}-\mathrm{N}$ in the filtered samples were diluted (with a dilution factor of 103) and analyzed using Hack Lange test kits of LCK 349 and LCK 304, respectively. Total suspended solids (TSS) retained on the $1.2 \mu \mathrm{m}$ glass fiber filters (Whatman GF-C, GE Healthcare, Little Chalfont, UK) were determined using standard methods [25]. Samples were also taken, once a month, for E. coli and total coliform bacteria analysis from the effluent of the reactor and the filtrates to investigate the effects of the different filter media and the flow setup on pathogen reduction, following the standard analytical methods [25] using Colilert 18 test kits (IDEXX Laboratories Inc., Westbrook, ME, USA). In addition, macronutrients, $\mathrm{K}, \mathrm{Ca}, \mathrm{Mg}, \mathrm{S}$ and $\mathrm{Na}$, and selected heavy metals were analyzed from three samples of each sampling points using inductively coupled plasma mass spectrometry (ICP-MS, Oban, UK).

The amounts of organic matter, nitrogen and phosphorus that were retained in the filter column systems were calculated as the concentration difference between the influent and effluent COD, $\mathrm{NH}_{4}-\mathrm{N}$ and $\mathrm{PO}_{4}-\mathrm{P}$, respectively. The retention/removal ( $\left.\mathrm{R}, \%\right)$ of total COD, filtered COD and nitrogen and phosphorus within the filter columns, was calculated according to the following equation:

$$
\mathrm{R}=(1-\mathrm{Ce} / \mathrm{Ci}) \times 100
$$

where $\mathrm{Ce}$ is the effluent concentration and $\mathrm{Ci}$ is the influent concentration. 


\section{Results and Discussions}

\subsection{Composition of Anaerobically Digested Blackwater Effluent}

The raw blackwater contains more particulate organic and particulate phosphate fractions. The dissolved organic fraction in the raw blackwater constituted only $24 \%$. Similar values are also reported in literature [23]. Likewise, the soluble phosphate fraction was $42 \%$ of the total P. Hydrolysis and fermentation in the anaerobic process resulted in the breakdown and solubilization of particulate organic matter and proteinaceous biomass. Subsequently, the effluent of anaerobically digested blackwater contained more than $60 \%$ dissolved organic fractions, which was $36 \%$ more than in the raw blackwater. Moreover, the anaerobically digested effluent comprised a higher concentration of soluble fractions of $\mathrm{NH}_{4}-\mathrm{N}$ and $\mathrm{PO}_{4}-\mathrm{P}$. The increase in concentration of $\mathrm{NH}_{4}-\mathrm{N}$ in the digestate resulted from mineralization of organic nitrogen and reduction of N-fixing carbon compounds [26]. Up to $86 \%$ of the total $\mathrm{P}$ was recorded in the effluent of the anaerobic digestion, of which $82 \%$ was in the soluble fraction. This provides an opportunity to recover and recycle the nutrients from blackwater as a source of value creation for value-added agricultural and other biomass production such as algal production.

\subsection{Removal of Organic Matter and Suspended Solids}

As shown from Figure 2, both Cocos char and granulated activated carbon filters columns had similar effects $(p>0.05)$ and removed on average about $80 \%$ of residual total COD and $73 \%$ of the residual filtered COD. The removal efficiency of the carbon filters for both total and filtered COD were also stable during the eight-month operation. Most of the removal of COD in both treatments occurred in the upward flow mode. The contribution of the downward unsaturated flow mode was, however, insignificant $(p=0.32)$. The average removal efficiency of polonite for both total and filtered COD was not substantial. During the eight-month operation period, the removal efficiency in the polonite column was only $43 \%$ and $12 \%$ for the total and filtered COD, respectively. Figure 3 shows the total and filtered COD concentrations during the filtration study period. The filtered organic matter in the polonite columns' effluent reached saturation after 50 days (Figure 3 (right)). It was also observed that the removal efficiency for filtered COD became negative after 100 days, probably due to dissociation of soluble organics form the biofilm that developed over time.

○ CCCH_2 $\triangle$ GAC_2 * C-Pol_2

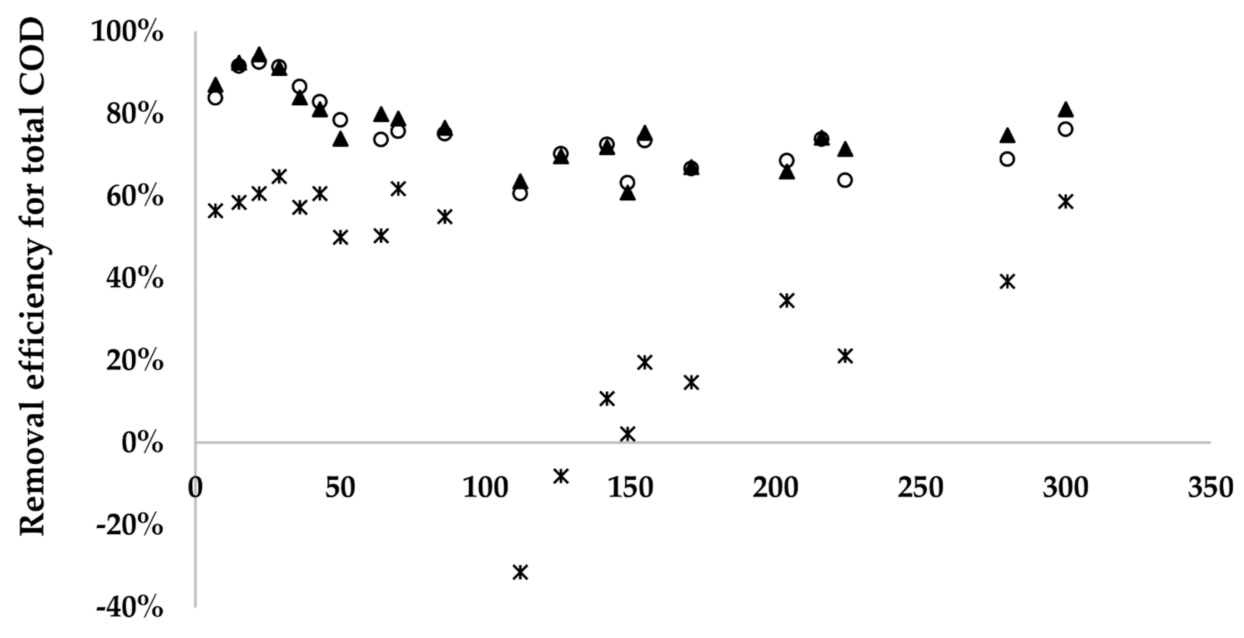

Figure 2. Cont. 


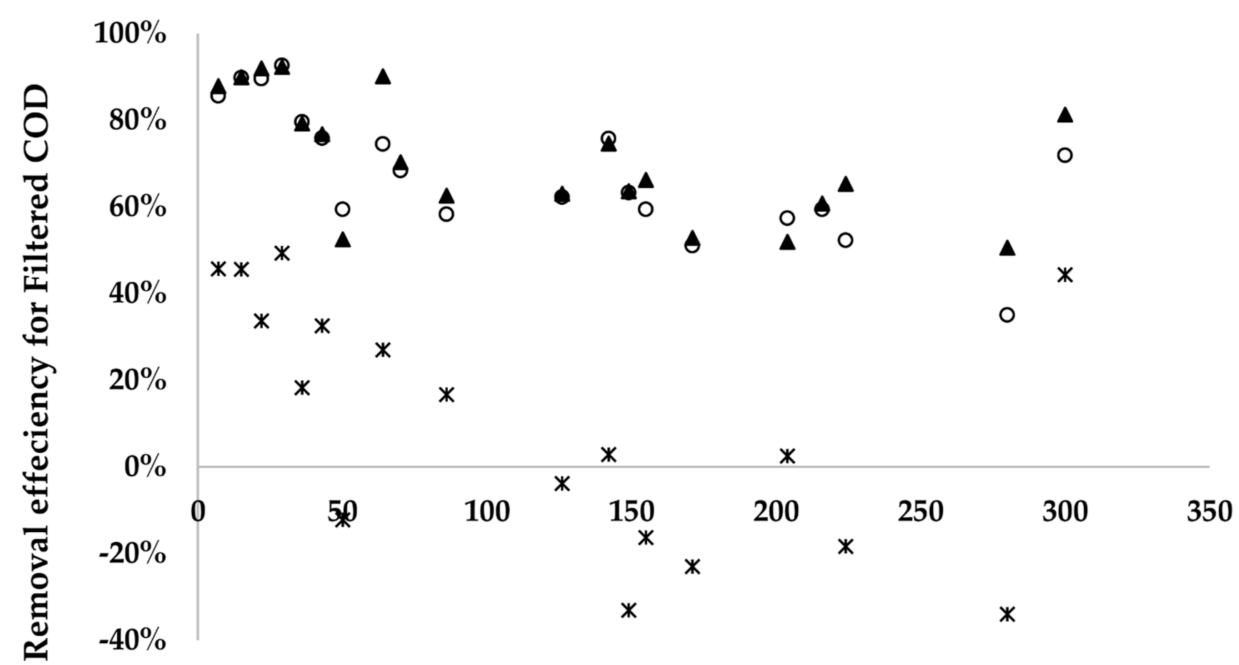

Time (Days)

Figure 2. Total chemical oxygen demand (COD) (top) and filtered COD (bottom) removal efficiency of Cocos char (CCCH_2), granular activated carbon (GAC_2), and coarse polonite (C-Pol_2).

The filtration step removed more than $90 \%$ of the residual suspended solids from the anaerobically digested effluent. Although the contribution from the downflow filtration step to the removal of COD, both total and filtrated, was insignificant $(p=0.32)$ in all cases compared to the upflow column, this step significantly contributed to the removal of TSS (Figure 4). As an overall combined treatment chain, the anaerobic reactor and the carbon-filled filter columns achieved a removal efficiency of more than to $99 \%$ for TSS, i.e., from an average of $2700 \mathrm{mg} / \mathrm{L}$ in the raw blackwater to less than $10 \mathrm{mg} / \mathrm{L}$ in the effluents of the downflow columns. This also corresponds to a substantial reduction in turbidity and $U_{254}$ absorbance resulting $<10$ NTU and $93 \%$, respectively. The reduction in turbidity and UV absorbance is a prerequisite for pathogen disinfection.
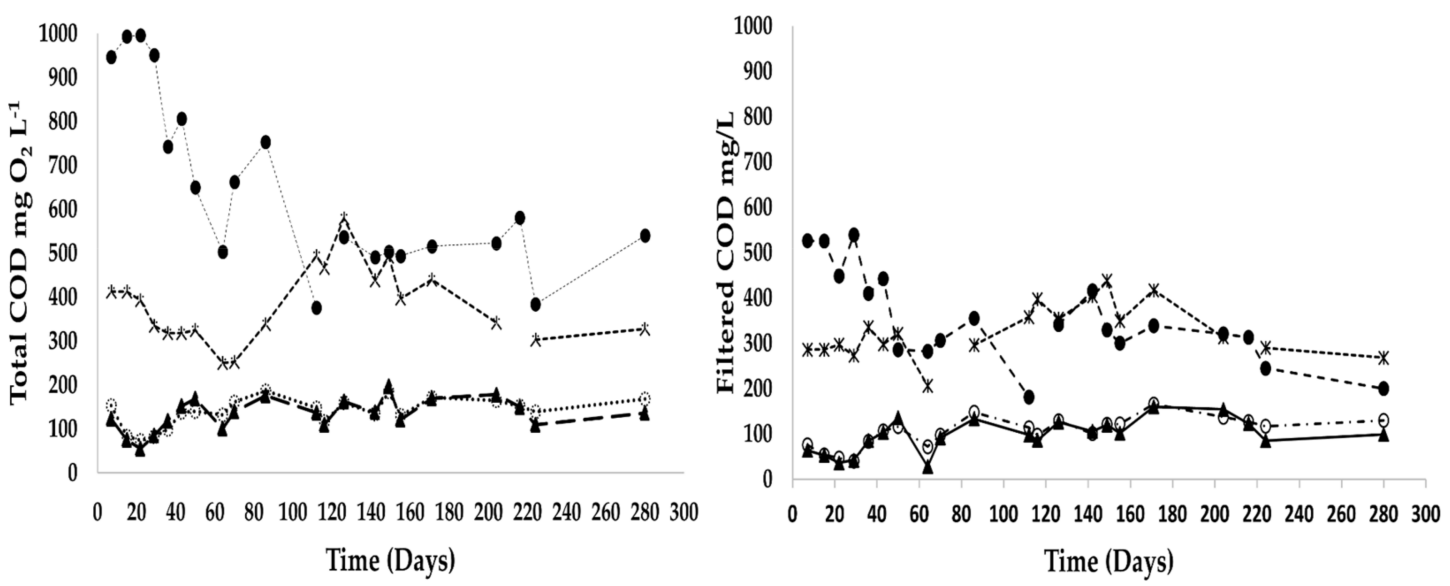

Figure 3. Total (left) and filtered (right) COD for the effluents of the anaerobic reactor (UASB II) and post-filter column effluents-Cocos char $\left(\mathrm{CCCH}_{-} 2\right)$, granular activated carbon (GAC_2), and coarse polonite (C-Pol_2). 


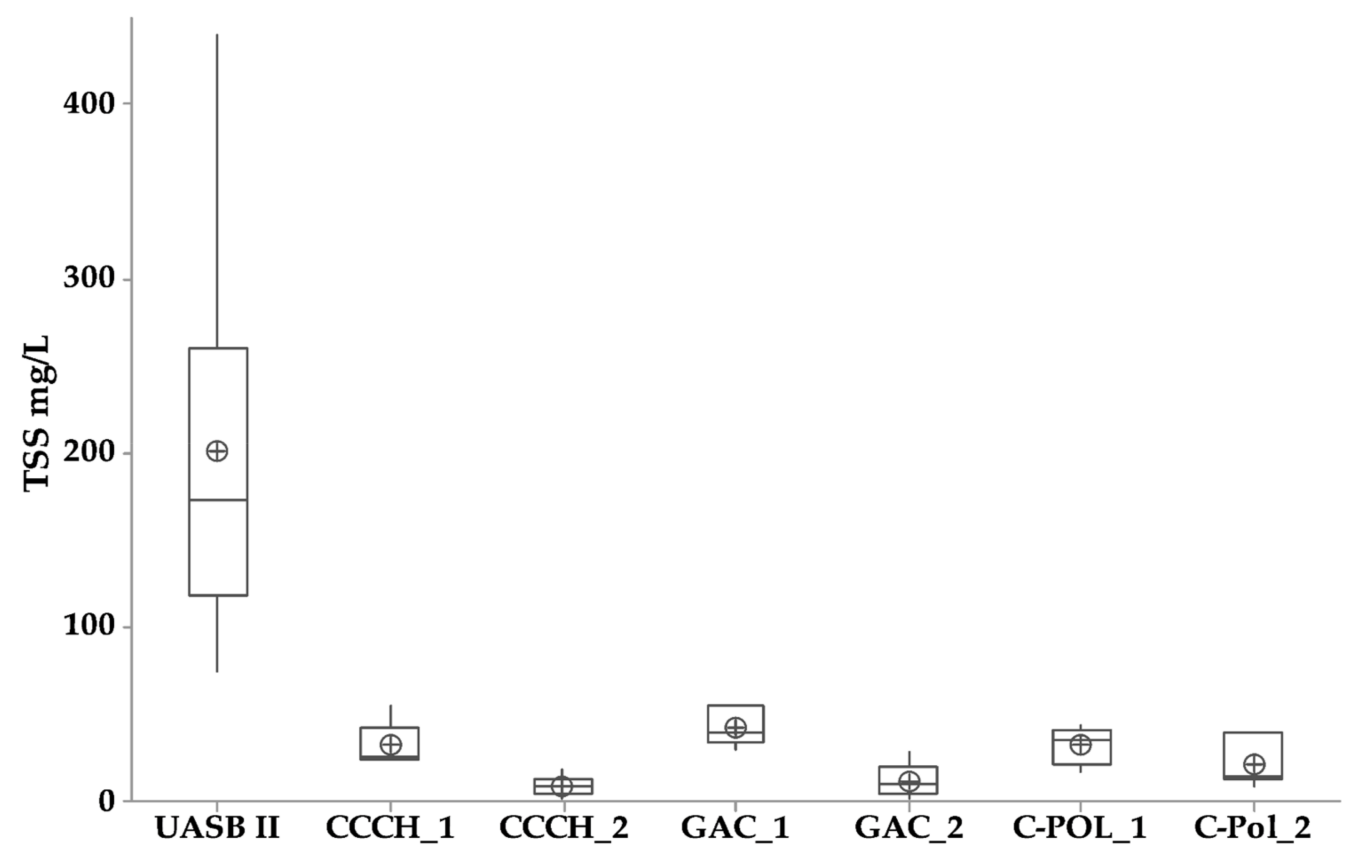

Figure 4. Total suspended solids (TSS) concentration of effluents of the UASB anaerobic rector (UASB II), upflow Cocos char column (CCCH_1) downflow Cocos char ( $\mathrm{CCCH} 2)$, upflow granular activated carbon (GAC_1) downward granular activated carbon (GAC_2), upflow coarse polonite (C-Pol_1) and downflow coarse polonite (C-Pol_2).

\subsection{Nutrient Recovery from Anaerobically Digested Blackwater Effluent}

During anaerobic treatment, the soluble fraction of phosphate concentration increased from on average $42 \mathrm{mg} \mathrm{PO}_{4}-\mathrm{P} \mathrm{L}^{-1}$ in the raw blackwater to $63 \mathrm{mg} \mathrm{PO}_{4}-\mathrm{P} \mathrm{L}^{-1}$. Similarly, the average $\mathrm{NH}_{4}-\mathrm{N}$ concentration increased from $610 \mathrm{mg} \mathrm{L}^{-1}$ in raw blackwater to $720 \mathrm{mg} \mathrm{L}^{-1}$ in the anaerobic effluent. This could be mainly due to hydrolysis of organically bound particulate phosphorus and a decrease in $\mathrm{pH}$ during anaerobic treatment (from about 9 in BW to 8.2 in the anaerobically digested effluent) which leads to the solubilizing of inorganic phosphates [27]. The filtration of nutrient-rich anaerobic effluent through adsorbent filters is a cost-effective way of recovering these nutrients. The system described here could offer nutrient recovery in two ways. First, preserving the nutrients adsorbed at the surface of the filter materials for later use as a slow-release fertilizer. The second and most important way was through selective removal of organic matter and TSS and recovering N and P as a nutrient solution in a liquid phase.

\subsubsection{Phosphorus Recovery}

Figure 5 indicates the effect of the different filter materials on $\mathrm{PO}_{4}-\mathrm{P}$ concentrations in the liquid-phase. Polonite showed high affinity to phosphate ions and higher phosphorus-retention efficiency has been observed in the polonite filtration column. Polonite exhibited a complete retention $(100 \%)$ of phosphate in the first two weeks of the experiment and then stabilized between $70 \%$ and $92 \%$ retention until the fourth month. On the other hand, more than $85 \%$ of the $\mathrm{PO}_{4}-\mathrm{P}$ is released in the liquid phase in the case of the carbon-based filter columns. This $\mathrm{PO}_{4}-\mathrm{P}$ can be harvested as nutrient solution together with other plant nutrients or can be recovered in the form of struvite or Ca- $\mathrm{PO}_{4}-\mathrm{P}$. 


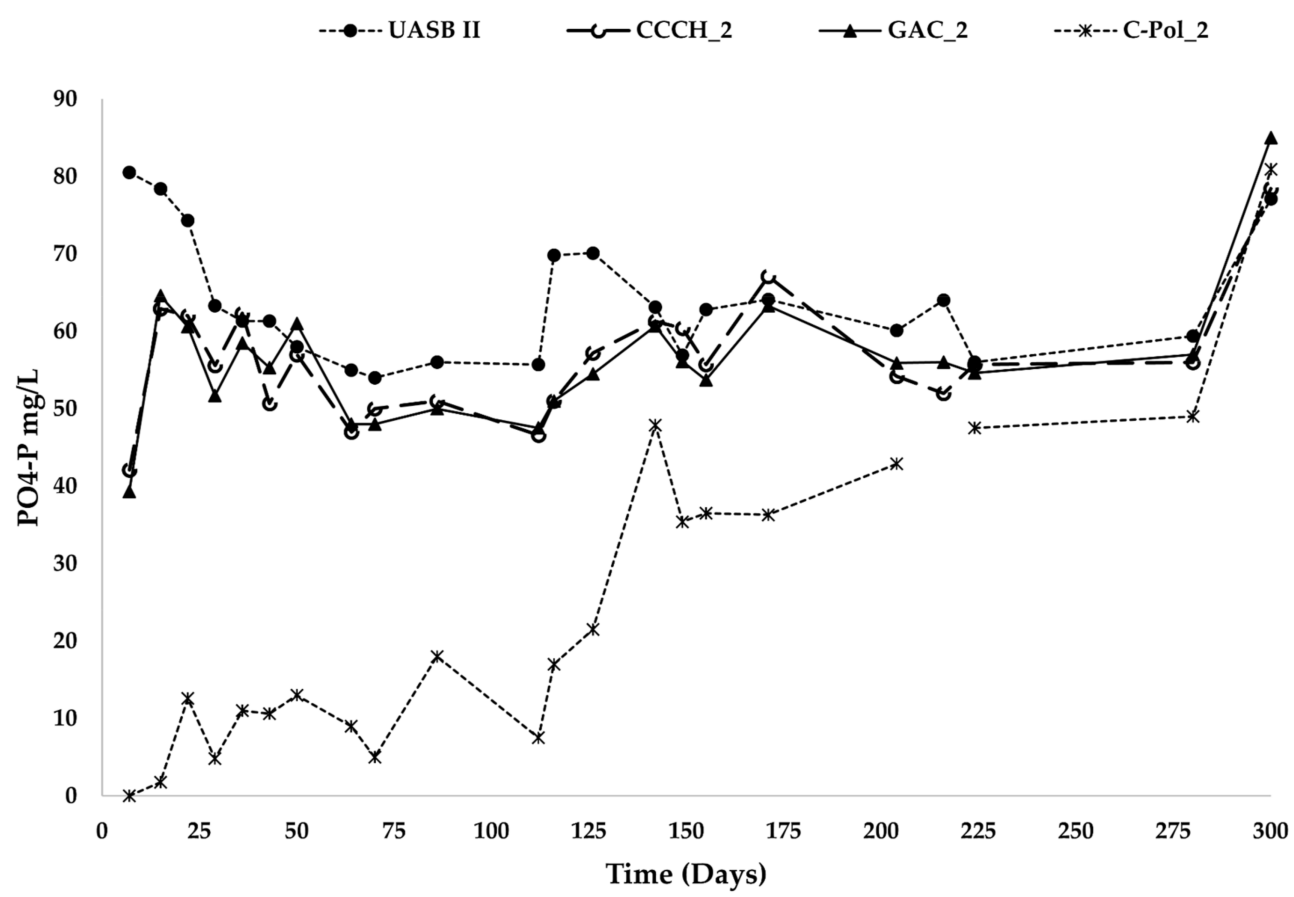

Figure 5. $\mathrm{PO}_{4}-\mathrm{P}$ concentrations in the liquid-phase for effluents of the anaerobic reactor (UASB II) and filtration columns-Cocos char ( $\left.\mathrm{CCCH} \_2\right)$, granular activated carbon (GAC_2), and coarse polonite (C-Pol_2).

The complete removal of phosphate by the polonite filter column in the first two weeks could be attributed to the high $\mathrm{pH}$ (above 10.6), the increased adsorption at the calcium-silicate surfaces, and precipitation by dissolved calcium [28]. However, the $\mathrm{PO}_{4}-\mathrm{P}$ removal efficiency of the polonite column dropped to $24-42 \%$ after 140 days and to $15-18 \%$ after 240 days. Studies indicated that sorption of organic compounds to the mineral surface increases the negative charge or decreases the point of zero charge (PZC) [29]. Furthermore, the formation of biofilm at the surface of the polonite particles and simultaneous sorption of organic ions by the mineral surfaces could also alter the surface charge and cause phosphate ions to be electrostatically repelled. This inhibition of $\mathrm{P}$ sorption due to increased repulsion from the negatively charged surface might be the cause for the sharp increase of phosphate concentration in the effluent from the polonite filter column. The reduction of phosphate removal after 140 days could also be associated with the drop in $\mathrm{pH}$ to less than 8 . The high organic load has also been found to reduce the lifetime of polonite considerably by preventing access to $P$ on the adsorbed site of the filter material [30]. It was also observed that the presence of organic ligands could inhibit the precipitation of calcium phosphates, one of the principal mechanisms for $\mathrm{P}$ removal in polonite [31]. Consequently, when the polonite is saturated with the soluble organic matter, the polonite surface affinity to $\mathrm{PO}_{4}-\mathrm{P}$ decreases and more phosphate ions will be released into the liquid phase.

Saturation of phosphate in the carbon filter column was reached in about 30 days compared to the polonite, which took 280 days. The low phosphorus-retention capacity observed in the carbon-based adsorbent could be attributed to its surface characteristics and the presence of a large amount of soluble organic ions. Previous studies have revealed that the surface of the biochar is often negatively charged, making it repel negatively charged ions such as phosphate [32,33]. Carbon-based adsorbents have a high affinity for organic ions [34] suggesting that soluble organic substances derived from hydrolysis and degradation in the anaerobic digestion are adsorbed first and occupy the sorption sites, thereby limiting P sorption. Moreover, the existence of high concentrations of bicarbonate in the solution reduced the phosphate adsorption [35]. High pH (higher than 7.8) of the anaerobically digested blackwater effluents can result in competitive reactions taking place 
between hydroxyl and phosphate ions [36], thereby occupying the available adsorption sites on the carbon-based adsorbents.

\subsubsection{Ammonium-Nitrogen Recovery}

Adsorption of $\mathrm{NH}_{4}-\mathrm{N}$ on the polonite column was significantly higher than on the two carbon columns ( $p=0.035$ for the Cocos char column and $p=0.024$ for the granular activated carbon column). On average, only $22 \% \mathrm{NH}_{4}-\mathrm{N}$ was retained in the carbon filter column. The high initial $\mathrm{pH}$ measured from polonite effluent at an early stage may suggest the loss of $\mathrm{NH}_{4}-\mathrm{N}$ in the first week due to the stripping of $\mathrm{NH}_{3}$. The decrease in effluent $\mathrm{NH}_{4}-\mathrm{N}$ concentration observed in the polonite column at the later stage could also result from microbial immobilization and nitrification due to the biofilm's development [37]. This is explained by the higher nitrite and nitrate concentrations in the polonite effluent compared to that in the other columns.

More than $75 \%$ of the $\mathrm{NH}_{4}-\mathrm{N}$ from the anaerobic effluent, on average $570 \mathrm{mg} \mathrm{L}^{-1}$, was released into the liquid phase from the carbon filtration column (Figure 6). Recovery of this valuable nutrient as liquid $\mathrm{N}$ fertilizer together with $\mathrm{P}$ and $\mathrm{K}$, therefore, adds value to the circular economy and at the same time reduces its impact on environmental pollution. This demonstrates the potential of domestic wastewater to supply readily available liquid $\mathrm{N}$ fertilizer for local biomass production and reduce the use of chemical nitrogen fertilizer produced using a high-energy intensive Haber-Bosch process [29]. Substituting just 5\% of the existing global nitrogen fertilizer production with $\mathrm{N}$ from domestic wastewater would save more than 50 terawatt-hours of energy [26]. Utilizing this untapped resource with the less-energy intensive method is, therefore, fundamental. Moreover, the nitrification-denitrification process for removal of $\mathrm{N}$ from wastewater requires more energy and at the same time releases nitric oxide $(\mathrm{NO})$ and nitrous oxide $\left(\mathrm{N}_{2} \mathrm{O}\right)$ to the atmosphere, which has harmful effects on the environment (greenhouse gases and acidification). Selecting filter materials for nutrient recovery involves analysis of the adsorption capacity of the filter materials for the different substances in blackwater. For $\mathrm{N}$ and $\mathrm{P}$ to be in the liquid phase, choosing filter materials that can selectively remove particulate and dissolved organic fractions including micropollutants, suspended solids, heavy metals and pathogens, is a necessity.

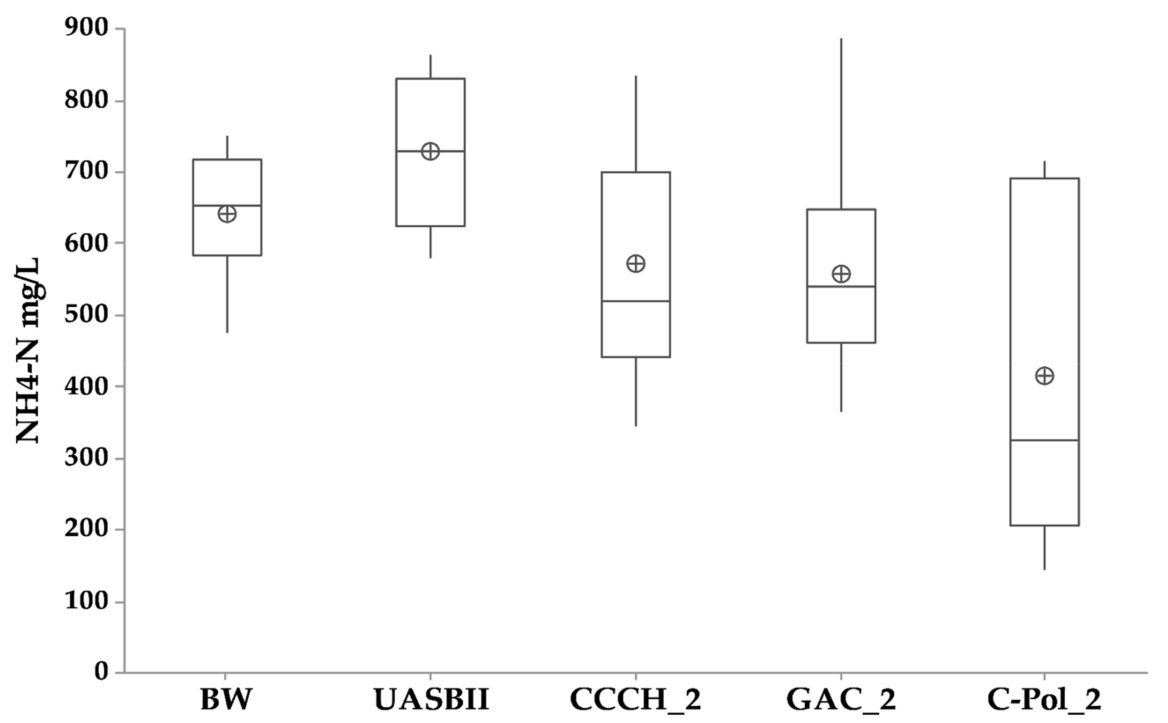

Figure 6. $\mathrm{NH}_{4}-\mathrm{N}$ concentrations in the liquid phase for raw blackwater (BW), effluents of the anaerobic reactor (UASB II) and filtration columns-Cocos char (CCCH_2), granular activated carbon (AGC_2), and coarse polonite (C-Pol_2). 


\subsubsection{Other Essential Macronutrient Concentrations in the Raw Blackwater and Effluents}

Figure 7 presents the average concentrations of the other macronutrients $(\mathrm{K}, \mathrm{Ca}, \mathrm{Mg}, \mathrm{S}, \mathrm{Na})$ from three grab samples from each sampling point. It was revealed that in addition to the $\mathrm{N}$ and $\mathrm{P}$, the $\mathrm{K}$ concentration in the liquid phase was higher in the carbon-based filtered effluents than the polonite. The concentration of $\mathrm{K}$ in these effluents reaches up to $190 \mathrm{mg} / \mathrm{L}$ compared to $67 \mathrm{mg} / \mathrm{L}$ for the raw blackwater.

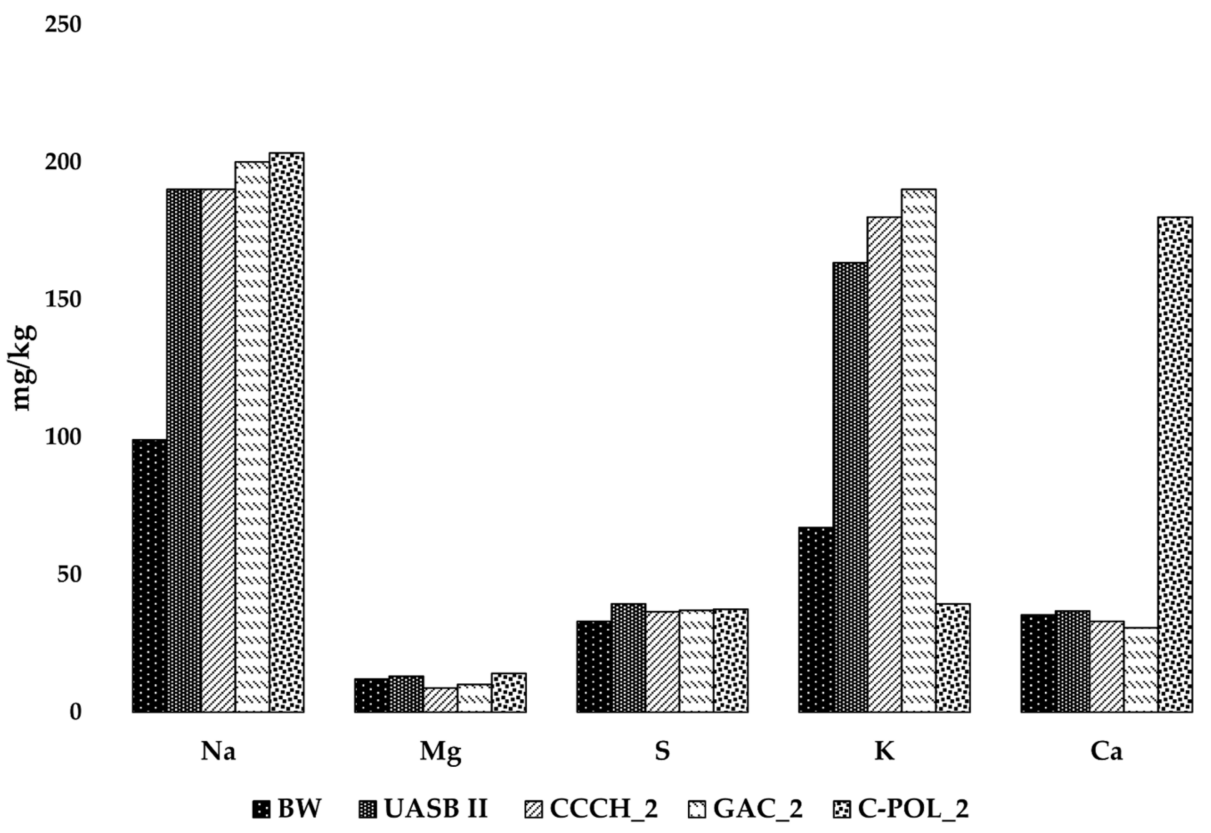

Figure 7. Macronutrient concentrations in raw blackwater (BW), anaerobic effluents (UASB I and UASB II), and filtration columns-Cocos char (CCCH_2), granular activated carbon (GAC_2), and coarse polonite (C-POL_2).

However, Ca was found in higher concentration in the polonite-filtered effluent than in the carbon-filtered effluent and in the raw blackwater and anaerobically treated blackwater effluents (Figure 7). This could be due to the solubilization of the Ca from the Ca-rich aluminosilicate polonite. This was also indicated from the release of $\mathrm{Fe}$ and $\mathrm{Al}$ in this column as a result of the dissolution of the aluminosilicate (Figure 8). The Mg concentration in the raw blackwater, anaerobic effluent, and filtration effluent was very low compared to the other macronutrients.

\subsubsection{Micronutrients and Heavy Metals}

Figure 8 shows the concentration of selected micronutrients and heavy metals in the raw blackwater, anaerobically treated effluent and filtration effluent. The heavy metal concentrations particularly As $(<10 \mu \mathrm{g} / \mathrm{L}), \mathrm{Cd}, \mathrm{Cr}, \mathrm{Co}$, and $\mathrm{Ni}$ in the raw blackwater as well as in the effluents were lower than even the threshold level in drinking water stated in the guidelines for drinking-water quality [38] suggesting low heavy metal risk if sanitized blackwater is used as source of plant nutrients. The heavy metal concentration in blackwater was by far lower than their presence in sewage sludge, livestock manure and artificial fertilizer, and comparable results were reported in the Netherlands [39]. As shown from Figure 8, the carbon filter columns substantially reduced $\mathrm{Al}, \mathrm{Fe}, \mathrm{Mn}, \mathrm{Cu}$ and $\mathrm{Zn}$ minimizing. On the other hand, the concentrations of $\mathrm{Al}, \mathrm{Fe}, \mathrm{Mn}$ and $\mathrm{Zn}$ in the polonite effluent are higher than the corresponding values in the anaerobically digested effluent. This might be due to the fact that polonite contains $\mathrm{Ca}, \mathrm{Al}$ and $\mathrm{Fe}$ silicate as the main components and small fraction of $\mathrm{Mn}$. The relatively high concentration of these heavy metals in polonite-filtered effluent could result from dissolution of these elements from the polonite. 


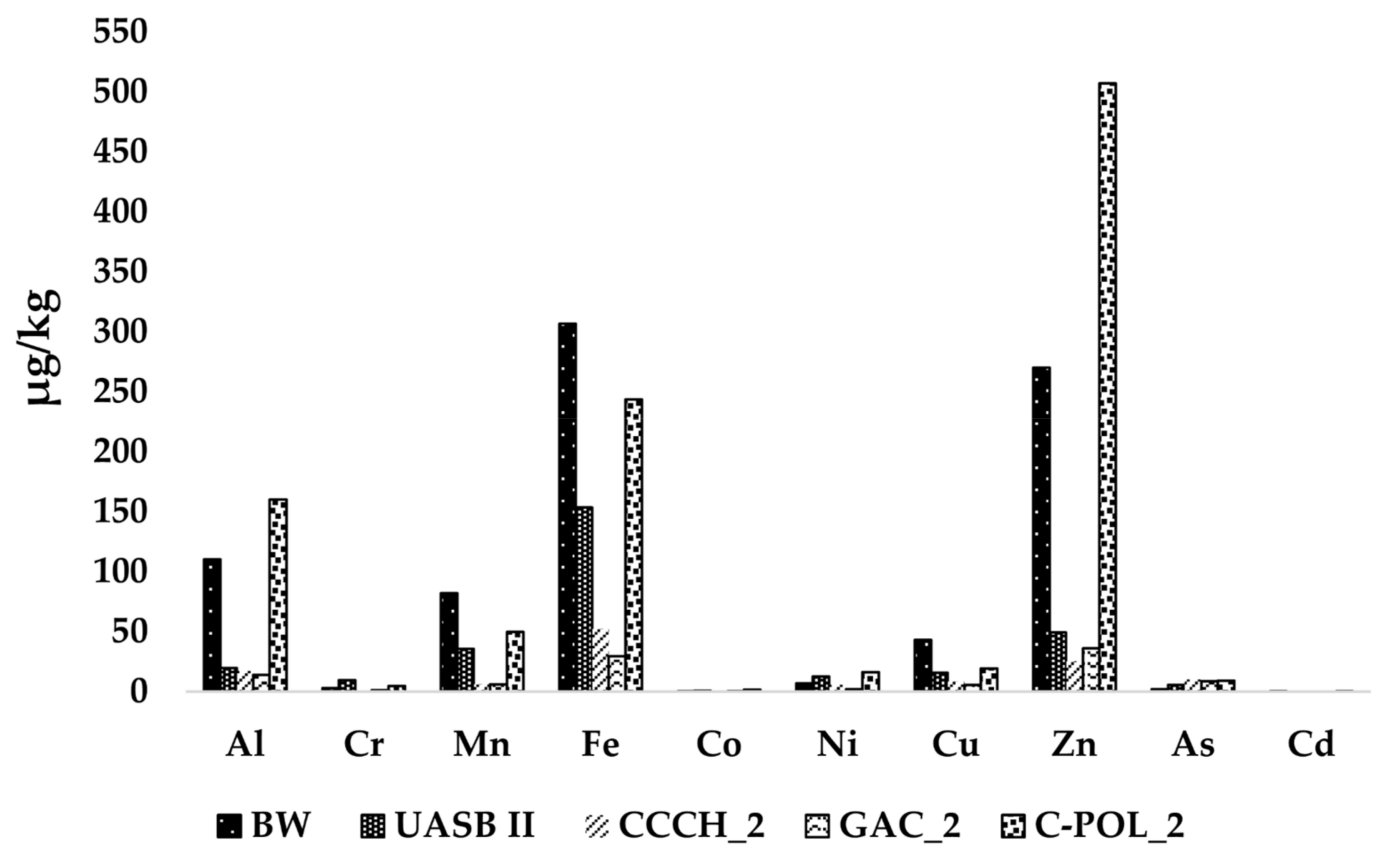

Figure 8. Micronutrient and heavy metal concentrations in raw blackwater (BW), anaerobic effluents (UASB I and UASB II), and filtration columns-Cocos char ( $\mathrm{CCCH} 2)$, granular activated carbon (GAC_2), and coarse polonite (C-POL_2).

This study revealed the potential of safe recovery of N, P and K from source-separated blackwater as a nutrient solution in a liquid phase and can be used locally for various purposes with low risk of heavy metals, pathogens and micropollutants. Additionally, the system overcomes the challenges of source-separated blackwater including many of the unpleasant aspects, mainly to do with smell and aesthetics, the need for long-term storage for disinfection, and the risks of unwanted precipitation of phosphorus compounds and ammonia volatilization. Along these lines, it is possible to enhance recycling to better close the nutrient loop, contribute to the green circular economy, and protect the environment. For large-scale applications, this nutrient solution could be used as a raw material for the production of concentrated nutrients. Moreover, if blackwater is collected and treated separately, not only are resources recovered, but also energy, chemicals and resources are saved in conventional wastewater treatment plants that are normally required for removal of the high organic matter, nitrogen and phosphorous emanating from toilets. This approach also allows a more specific treatment and selective removal systems for the control of pathogens and micro-pollutants at the source.

\subsection{Pathogen Removal in the Treatment Chain}

The E. coli concentration in the raw blackwater was on average $1.275 \times 10^{7} \mathrm{MPN} / 100 \mathrm{~mL}$. The log reduction of $E$. coli in the anaerobic digestion stage ranged from $1.3 \log$ to $2.4 \log$ with an average reduction of about $1.86 \mathrm{log}$. Anaerobic treatment systems are not designed to remove pathogens to a level that meet the required regulations [40] but greatly contribute to post-treatment of the effluent by reducing the particulate organic matter and total suspended solids. The major concern in the treatment and direct reuse of anaerobically digested blackwater is, therefore, the associated health risk from pathogens [26]. In order to comply with local regulations for reuse or discharge and control of the health risk from pathogens, disinfection mechanisms need to be integrated. Figures 9 and 10 show the effects of anaerobic digestion, filtration and UV light on E. coli removal and cumulative E. coli $\log$ reduction, respectively.

The polonite filtration column completely removed $E$. coli in the first two weeks. This was mainly attributed to the high $\mathrm{pH}$ 10.6. At this $\mathrm{pH}$, microorganisms are inactivated and their regrowth 
is restricted. Over time, the $\mathrm{pH}$ in the column decreased and, consequently, the efficiency of pathogen removal was reduced. The pathogen-removal efficiency of the carbon columns was lower than expected. However, efficient removal of organic matter, TSS, and correspondingly turbidity and $\mathrm{UV}_{254}$ absorbance by the carbon filter columns made it feasible for UV disinfection. The treated water from the carbon column that passed through a 11 Watt UV lamp had E. coli concentrations below the detection limit. The cumulative log reduction of E. coli thus reached $7 \log$ after the application of UV, achieving the sanitizing potential of the system and potential reduction of health-related risks from reuse or discharge perspectives.

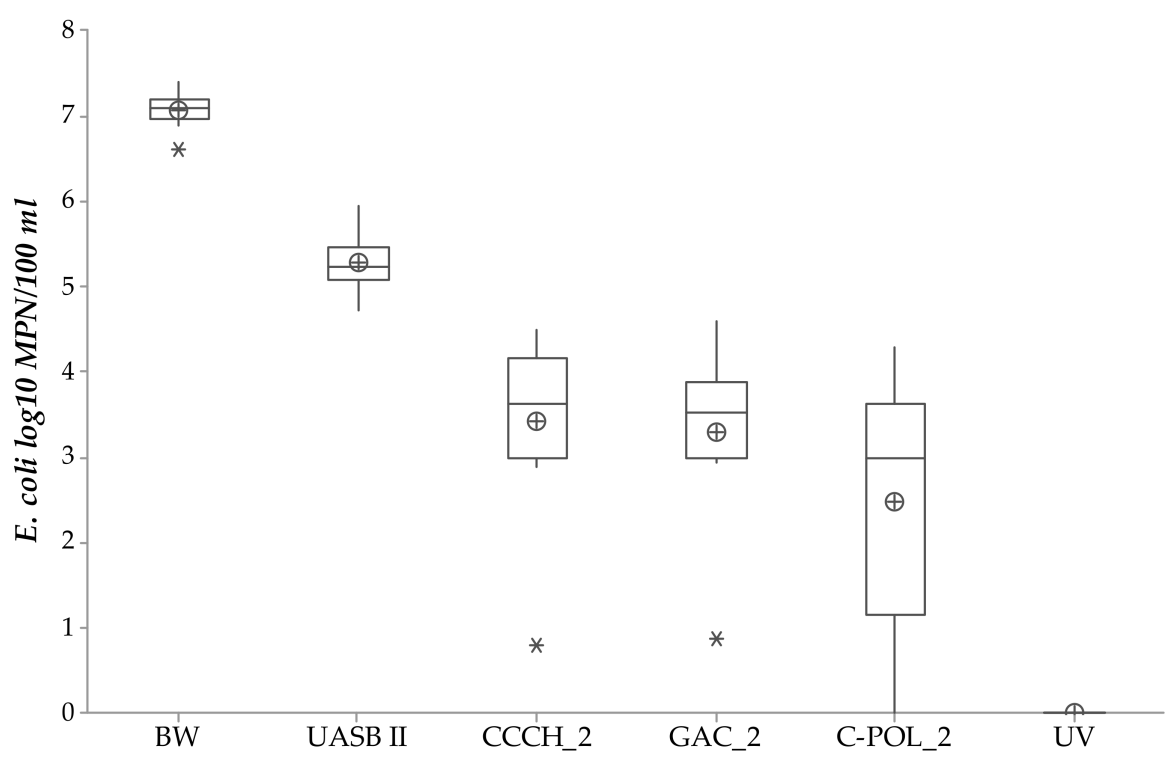

Figure 9. E. coli concentration of the raw blackwater (BW), reactor effluent (UASB II), in the effluents of filtration columns-Cocos char ( $\left.\mathrm{CCCH} \_2\right)$, granular activated carbon (GAC_2), and coarse Polonite (C-POL_2) at different levels of treatments, and after ultraviolet light treatment (UV).

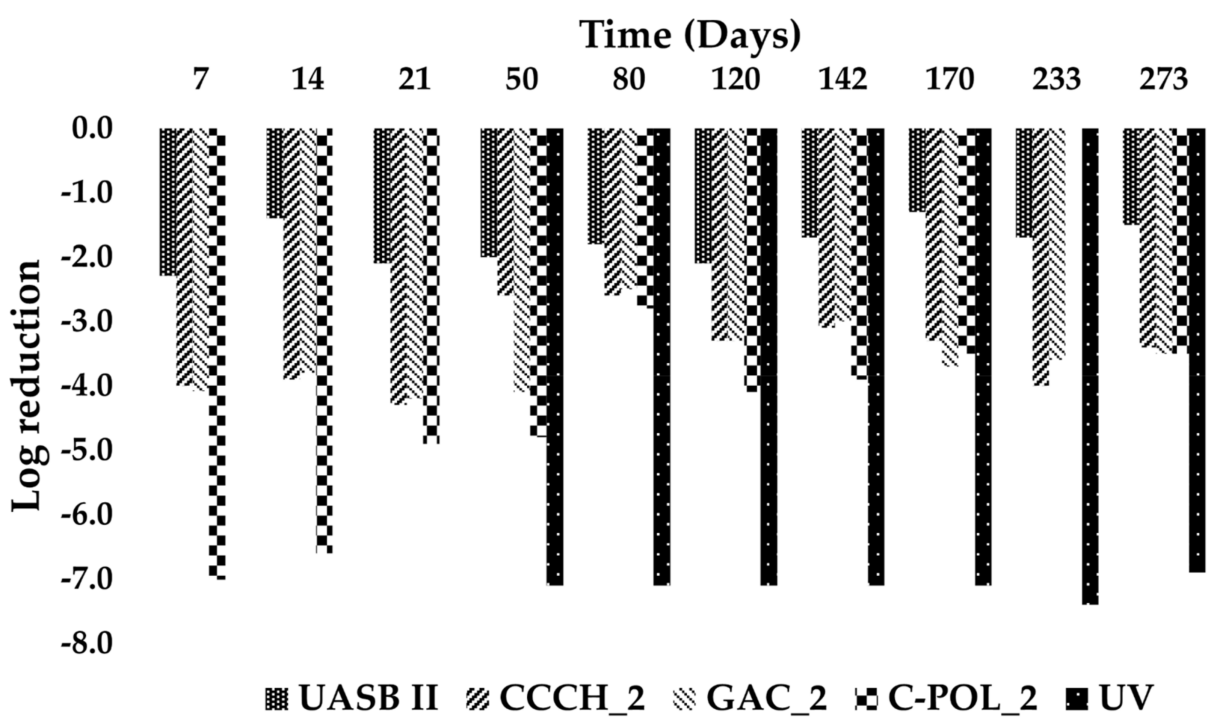

Figure 10. Cumulative log reduction E. coli of by the different treatments (reactor effluent (UASB II), in the effluents of filtration columns-Cocos char (CCCH_2), granular activated carbon (GAC_2), and coarse polonite (C-POL_2) at different levels of treatments, and after UV treatment (UV)) at different sampling times during the study period. 


\section{Conclusions}

This study demonstrated opportunities for a combined treatment and sustainable resource recovery from source-separated blackwater through systematic integration of a sludge blanket anaerobic-baffled reactor and a novel compacted filtration system. The system achieved a high effluent quality in terms of organic matter, TSS, turbidity and indicator bacteria. Both carbon-based filters removed $80 \%$ of the residual organic matter, more than $90 \%$ of residual TSS, and $93 \%$ of the turbidity and $\mathrm{UV}_{254}$ absorbance from the effluent of the anaerobic reactor. Efficient removal of organic matter, TSS, turbidity and an increase in UV transmission makes the system further feasible for UV disinfection.

With carbon filtration, the majority of nutrients, on average about $570 \mathrm{mg} / \mathrm{L} \mathrm{NH}_{4}-\mathrm{N}, 56 \mathrm{mg} / \mathrm{L}$ of $\mathrm{PO}_{4}-\mathrm{P}$ and $190 \mathrm{mg} / \mathrm{L}$ of $\mathrm{K}$, remained in the liquid phase. Hence, the liquid effluent consisted of a highly valuable fertilizer which can be reintroduced as a nutrient solution in the production system aiming towards a circular economy. Phosphorus and ammonium recovery from blackwater in this way, in turn, reduces the unwanted enrichment of surface water, thereby reducing the associated environmental impact. Particular heavy metals still present in digested BW are reduced notably in the filter columns so that an effluent quality well within the present guidelines for organic fertilizers can be ensured. Moreover, the system overcomes the challenges of source-separated blackwater including many of the unpleasant aspects to do with smell and aesthetics, the need for long-term storage for disinfection, and the risks of unwanted precipitation of phosphorus compounds.

Integration of anaerobic digestion of source-separated blackwater with filtration and UV as novel post-treatment steps resulted in effluent quality that meets levels demanded and opens up the opportunity of reusing the valuable resources from blackwater for a range of end-use options without compromising public health and the environment.

Acknowledgments: The authors gratefully acknowledge financial support by Ecomotive AS and the Norwegian Research Council (NRC). Special thanks are extended to Frida Celius Kalheim (MSc students) for assisting in blackwater analysis. We also thank Arne Svendsen and Oliver Sahlmann for their technical support in the installation and maintenance of the columns.

Author Contributions: The corresponding author, Melesse Eshetu Moges, conceived, designed and performed the experiment, collected and analyzed the data, and drafted the manuscript. Arve Heistad and Daniel Todt provided the required support in the experimental design and critically reviewed and commented on the manuscript. All authors have read and approved the final manuscript.

Conflicts of Interest: The authors declare no conflict of interest.

\section{References}

1. Cordell, D.; Drangert, J.-O.; White, S. The Story of Phosphorus: Global Food Security and Food for Thought. Glob. Environ. Chang. 2009, 19, 292-305. [CrossRef]

2. Galloway, J.N.; Cowling, E.B. Reactive Nitrogen and the World: 200 Years of Change. AMBIO J. Hum. Environ. 2002, 31, 64-71. [CrossRef]

3. Carey, D.E.; Yang, Y.; McNamara, P.J.; Mayer, B.K. Recovery of Agricultural Nutrients from Biorefineries. Bioresour. Technol. 2016, 215, 186-198. [CrossRef] [PubMed]

4. Batstone, D.J.; Hülsen, T.; Mehta, C.M.; Keller, J. Platforms for Energy and Nutrient Recovery from Domestic Wastewater: A Review. Chemosphere 2015, 140, 2-11. [CrossRef] [PubMed]

5. Matassa, S.; Batstone, D.J.; Hülsen, T.; Schnoor, J.; Verstraete, W. Can Direct Conversion of Used Nitrogen to New Feed and Protein Help Feed the World? Environ. Sci. Technol. 2015, 49, 5247-5254. [CrossRef] [PubMed]

6. Vinneras, B.; Palmquist, P.; Balmer, P.; Jonsson, H. The Characteristics of Household Wastewater and Biodegradable Solid Waste-A Proposal for New Swedish Design Values. Urban Water J. 2006, 3, 3-11. [CrossRef]

7. Todt, D.; Heistad, A.; Jenssen, P.D. Load and Distribution of Organic Matter and Nutrients in a Separated Household Wastewater Stream. Environ. Technol. 2015, 36, 1584-1593. [CrossRef] [PubMed]

8. Wilderer, P.A.; Schreff, D. Decentralized and Centralized Wastewater Management: A Challenge for Technology Developers. Water Sci. Technol. 2000, 41, 1-8. 
9. Larsen, T.A.; Hoffmann, S.; Lüthi, C.; Truffer, B.; Maurer, M. Emerging Solutions to the Water Challenges of an Urbanizing World. Science 2016, 352, 928-933. [CrossRef] [PubMed]

10. Langergraber, G.; Muellegger, E. Ecological Sanitation-A Way to Solve Global Sanitation Problems? Environ. Int. 2005, 31, 433-444. [CrossRef] [PubMed]

11. McConville, J.R.; Kvarnström, E.; Jönsson, H.; Kärrman, E.; Johansson, M. Source Separation: Challenges \& Opportunities for Transition in the Swedish Wastewater Sector. Resour. Conserv. Recycl. 2017, 120, 144-156.

12. Zoboli, O.; Zessner, M.; Rechberger, H. Supporting Phosphorus Management in Austria: Potential, Priorities and Limitations. Sci. Total Environ. 2016, 565, 313-323. [CrossRef] [PubMed]

13. Larsen, T.A.; Alder, A.C.; Eggen, R.I.L.; Maurer, M.; Lienert, J. Source Separation: Will We See a Paradigm Shift in Wastewater Handling? Environ. Sci. Technol. 2009, 43, 6121-6125. [CrossRef] [PubMed]

14. Metcalf \& Eddy Inc. an AECOM Company; Asano, T.; Burton, F.L.; Leverenz, H.L.; Tsuchihashi, R.; Tchobanoglous, G. Water Reuse Applications: An Overview. In Water Reuse: Issues, Technologies, and Applications; McGraw Hill: New York, NY, USA, 2007.

15. McCarty, P.L.; Bae, J.; Kim, J. Domestic Wastewater Treatment as a Net Energy Producer-Can This Be Achieved? Environ. Sci. Technol. 2011, 45, 7100-7106. [CrossRef] [PubMed]

16. Bracken, P.; Wachtler, A.; Panesar, A.R.; Lange, J. The Road Not Taken: How Traditional Excreta and Greywater Management May Point the Way to a Sustainable Future. Water Sci. Technol. Water Supply 2007, 7, 219-227. [CrossRef]

17. Guest, J.S.; Skerlos, S.J.; Barnard, J.L.; Beck, M.B.; Daigger, G.T.; Hilger, H.; Jackson, S.J.; Karvazy, K.; Kelly, L.; Macpherson, L. A New Planning and Design Paradigm to Achieve Sustainable Resource Recovery from Wastewater. Environ. Sci. Technol. 2009, 43, 6126-6130. [CrossRef] [PubMed]

18. Van Lier, J.B. High-Rate Anaerobic Wastewater Treatment: Diversifying from End-of-the-Pipe Treatment to Resource-Oriented Conversion Techniques. Water Sci. Technol. 2008, 57, 1137-1148. [CrossRef] [PubMed]

19. Medina, V.F.; Scholze, R.J.; Waisner, S.A.; Griggs, C.S. Energy and Resource Recovery from Wastewater Treatment: State of the Art and Potential Application for the Army and the Dod; Engineer Research and Development Center \& Construction Engineering Research Lab: Champaign, IL, USA, 2015.

20. Zeeman, G.; Kujawa-Roeleveld, K. Resource Recovery from Source Separated Domestic Waste (Water) Streams; Full-Scale Results. Water Sci. Technol. 2011, 64, 1987-1992. [CrossRef] [PubMed]

21. De Graaff, M.S.; Temmink, H.; Zeeman, G.; Buisman, C.J.N. Anaerobic Treatment of Concentrated Black Water in a Uasb Reactor at a Short Hrt. Water 2010, 2, 101-119. [CrossRef]

22. Jenssen, P.D.; Heyerdahl, P.H.; Warner, W.S.; Greatorex, J.M. Local Recycling of Wastewater and Wet Organic Waste-a Step Towards the Zero-Emission Community. In Proceedings of the 8th International Conference on Environmental Technology, Lemnos Island, Greece, 8-10 September 2003.

23. Kujawa-Roeleveld, K.; Zeeman, G. Anaerobic Treatment in Decentralized and Source-Separation-Based. Rev. Environ. Sci. Bio/Technol. 2006, 5, 115-139. [CrossRef]

24. Moges, M.E.; Todt, D.; Janka, E.; Bakke, R.; Heistad, A. Sludge Blanket Anaerobic Baffled Reactor for Source-Separated Blackwater Treatment. Water Sci. Technol. 2018, in press.

25. American Public Health Association (APHA); American Water Work Association (AWWA); Water Environment Federation (WEF). Standard Methods for the Examination of Water and Wastewater, 21st ed.; American Public Health Association (APHA); American Water Work Association (AWWA); Water Environment Federation (WEF): Washington, DC, USA, 2005.

26. Winker, M.; Vinnerås, B.; Muskolus, A.; Arnold, U.; Clemens, J. Fertiliser Products from New Sanitation Systems: Their Potential Values and Risks. Bioresour. Technol. 2009, 100, 4090-4096. [CrossRef] [PubMed]

27. De Graaff, M.S.; Temmink, H.; Zeeman, G.; Buisman, C.J.N. Energy and Phosphorus Recovery from Black Water. Water Sci. Technol. 2011, 63, 2759-2765. [CrossRef] [PubMed]

28. Renman, A. On-Site Wastewater Treatment-Polonite and Other Filter Materials for Removal of Metals, Nitrogen and Phosphorus. Ph.D. Thesis, Royal Institute of Technology (KTH), Stockholm, Sweden, 2008.

29. Guppy, C.N.; Menzies, N.W.; Moody, P.W.; Blamey, F.P.C. Competitive Sorption Reactions between Phosphorus and Organic Matter in Soil: A Review. Soil Res. 2005, 43, 189-202. [CrossRef]

30. Nilsson, C.; Renman, G.; Westholm, L.J.; Renman, A.; Drizo, A. Effect of Organic Load on Phosphorus and Bacteria Removal from Wastewater Using Alkaline Filter Materials. Water Res. 2013, 47, 6289-6297. [CrossRef] [PubMed] 
31. Gustafsson, J.P.; Renman, A.; Renman, G.; Poll, K. Phosphate Removal by Mineral-Based Sorbents Used in Filters for Small-Scale Wastewater Treatment. Water Res. 2008, 42, 189-197. [CrossRef] [PubMed]

32. Eberhardt, T.L.; Min, S.; Han, J.S. Phosphate Removal by Refined Aspen Wood Fiber Treated with Carboxymethyl Cellulose and Ferrous Chloride. Bioresour. Technol. 2006, 97, 2371-2376. [CrossRef] [PubMed]

33. Yao, Y.; Gao, B.; Inyang, M.; Zimmerman, A.R.; Cao, X.; Pullammanappallil, P.; Yang, L. Biochar Derived from Anaerobically Digested Sugar Beet Tailings: Characterization and Phosphate Removal Potential. Bioresour. Technol. 2011, 102, 6273-6278. [CrossRef] [PubMed]

34. Erich, M.S.; Fitzgerald, C.B.; Porter, G.A. The Effect of Organic Amendments on Phosphorus Chemistry in a Potato Cropping System. Agric. Ecosyst. Environ. 2002, 88, 79-88. [CrossRef]

35. Yao, Y.; Gao, B.; Inyang, M.; Zimmerman, A.R.; Cao, X.; Pullammanappallil, P.; Yang, L. Removal of Phosphate from Aqueous Solution by Biochar Derived from Anaerobically Digested Sugar Beet Tailings. J. Hazard. Mater. 2011, 190, 501-507. [CrossRef] [PubMed]

36. Metcalf \& Eddy, Inc. Wastewater Engineering: Treatment, Disposal and Reuse, 4th ed.; McGraw Hill: New York, NY, USA, 2003.

37. Renman, A.; Hylander, L.D.; Renman, G. Transformation and Removal of Nitrogen in Reactive Bed Filter Materials Designed for on-Site Wastewater Treatment. Ecol. Eng. 2008, 34, 207-214. [CrossRef]

38. World Health Organization (WHO). Guidelines for Drinking-Water Quality: Recommendations; World Health Organization: Geneva, Switzerland, 2004; Volume 1.

39. Tervahauta, T.; Rani, S.; Leal, L.H.; Buisman, C.J.N.; Zeeman, G. Black Water Sludge Reuse in Agriculture: Are Heavy Metals a Problem? J. Hazard. Mater. 2014, 274, 229-236. [CrossRef] [PubMed]

40. De Chernicharo, C.A.L. Post-Treatment Options for the Anaerobic Treatment of Domestic Wastewater. Rev. Environ. Sci. Bio/Technol. 2006, 5, 73-92. [CrossRef]

(C) 2018 by the authors. Licensee MDPI, Basel, Switzerland. This article is an open access article distributed under the terms and conditions of the Creative Commons Attribution (CC BY) license (http:/ / creativecommons.org/licenses/by/4.0/). 